Original Paper

\title{
Budidaya Ramah Lingkungan Sebagai Strategi Pengentasan Kemiskinan Nelayan Skala Kecil Di Desa Ketapang Raya Lombok Timur
}

\author{
Abdul Syukur ${ }^{1 *}$, Khairudin'1, M. Yamin ${ }^{1}$ \\ ${ }^{1}$ Program Studi Pendidikan Biologi Fakultas Keguruan dan Ilmu Pendidikan, Universitas Mataram
}

*Corresponding Author:

Abdul Syukur, Program

Studi Pendidikan Biologi

Fakultas Keguruan dan

Ilmu Pendidikan,

Universitas Mataram,

Indonesia;

Email:

syukurbiologi@unram.ac.id

\begin{abstract}
Abstrak: Nelayan skala kecil sampai saat masih menjadi kelompok sasaran dalam program pengentasan kemiskinan. Program pengentasan kemiskinan nelayan skala kecil lebih berorientasi pada peningkatan kapasitas alat tangkap. Desa Ketapang Raya memiliki potensi lingkungan yang belum dikembangkan sebagai sumber produksi ikan dan biota laut lainnya yang bernilai ekonomi untuk meningkatkan ekonomi nelayan skala kecil. Potensi lingkungan tersebut adalah: (1) muara, (2) bekas sawah garam, (3) lahan kosong pada ekosistem mangove dan (4) daerah perairan pesisir pantai untuk budidaya. Oleh karena itu fokus program pengabdian pada masyarakat ini adalah pemanfaatan potensi lingkungan melalui budidaya ramah lingkungan sebagai strategi pengentasan kemiskinan nelayan skala kecil di Desa Ketapang Raya Lombok Timur. Pendekatan yang digunakan adalah pendekatan kooperatif melalui sistem pembelajaran orang dewasa (andragogi) dengan metode contoh (damplots), diskusi kelompok, Fokus Group Discussion (FGD) dan wawancara. Hasil yang dalam pengabdian pada masyarakat ini adalah pertama pembentukan kelompok budidaya ramah lingkungan nelayan skala kecil di Desa Ketapang Raya yaitu 'kelompok bintang laut", kedua kelompok nelayan sangat aktif dalam diskusi untuk melaksnakan budidaya ramah lingkungan teruama budidaya ikan dan kepeing bakau dan ketiga membuat contoh budidaya ikan yaitu ikan baronag dan udang lobster dengan sistem kramba jaring apung. Kesimpulannya bahwa pengabdian pada masyarakat ini memberikan dampak positif sebagai motipasi nelayan untuk mengembangkan budidaya ramah lingkungan sebagai alternatif dalam mengatasi kekeruangan hasil tangkapan ikan.
\end{abstract}

Kata Kunci: Budibaya ramah lingkungan; Kemiskinan; Nelayan

\section{Pendahuluan}

Nelayan skala kecil di lokasi kegiatan pengabdian pada masayarakat (Desa Ketapang Raya) jumlahnya lebih besar dari semua propfesi yang lain (Profil Desa Ketapang Raya, 2014). Saat ini produksi ikan hasil tangkapan nelayan, khususnya nelayan skala kecil di Desa Ketapang Raya terus mengalami penurunan dan ini diduga karena beberapa jenis ikan seperti: ikan lemuru, tembang, dan cumi-cumi di perairan laut Tanjung Luar dan sekitarnya (Selat Alas) sudah melampaui jumlah tangkapan yang diperbolehkan (Karnan et al., 2012a) dan pada jenis cumi-cumi sudah melampaui potensi lestarinya (Karnan et al., 2012b). Kondisi sumberdaya ikan saat ini di perairan laut yang menjadi areal tangkapan nelayan skala kecil dari Desa Ketapang Raya sudah tidak dapat dikembangkan untuk meningkatkan pendapatan keluarga nelayan. Hal ini dapat dilihat dari rata-rata pendapatan nelayan skala kecil di wilayah pesisir Tanjung Luar dan Desa Ketapang Raya sebesar Rp. 425.000,-/bulan (Diskanlut Lombok Timur, 2013).

Parameter-parameter seperti pendapatan nelayan skala kecil dan jumlah populasi nelayan adalah faktor utama yang menjadi fokus untuk mengatasi masalah kemiskinan nelayan skala kecil di Desa Ketapang Raya. Di sisi lain masyarakat lokal memiliki pengetahuan tentang perubahan ekosistem di wilayah pesisir secara spatial dan temporal, status biota laut yang bernilai ekonomi (Syukur, 2013). Oleh karena solusi pengetasan kemiskinan dapat bersumber dari sumberdaya lingkungan di Desa Ketapang Raya. Masyarakat dan nelayan skala kecil di Desa Ketapang Raya sebenarnya memiliki potensi yang bersifat responsif dalam mencari alternatif matapencaharian baru 
seperti sebagai penangkapan bibit lobster secara berkelompok dengan menggunakan sistem Keramba Apung (KA). Namun demikian usaha tersebut tidak dapat dilanjutkan dengan terbitnya Peraturan Menteri Kelautan dan Perikanan RI No 1 Tahun 2015 tentang ukuran penangkapan lobster (Panulirus spp.) yang diperbolehkan (Permen KKP No 1 2015). Namun demikian potensi beberapa famili ikan ekonomis penting seperti famili Siganidae, famili Lutjanidae, Haemulidae, famili Mullidae dan Mugilidae cukup potensial dikembangkan oleh nelayan kecil di lokasi studi (Syukur et al., 2014)..

Desa Ketapang Raya sebagai desa baru dari hasil pemekaran Desa Tanjung Luar memiliki potensi lingkungan yang cukup besar sebagai sumber ekonomi masyarakat. Potensi lingkungan yang ada di Desa Ketapang Raya adalah: (1) bekas sawah garam yang sudah tidak produktif, (2) muara, (3) lahan kosong pada ekosistem mangrove dan perairan pantai yang cukup luas. Berkaitan dengan besarnya potensi lingkungan untuk kegiatan budidaya ramah lingkungan tersebut dapat menjadi solusi dalam strategi mengatasi masalah kemiskinan nelayan skala kecil d Desa Ketapang Raya. Budidaya ramah lingkungan secara ekonomi adalah merupakan komplementri dari usaha perikanan tangkap dan dapat berkembang menjadi sumber matapencaharian utama yang berkelanjutan (Perez et al., 2012)..

\section{Metode Pelaksanaan}

Pengabdian pada masyarakat ini dilaksanakan di Desa Ketapang Raya Lombok Timur dari Juni 2015-Nopember 2015. Pengabdian pada masyarakat dengan topik kegiatan budidaya ramah lingkungan dalam pelaksanaannya sasaran utamanya adalaha kelompok nelayan skala kecil di Desa Ketapang Raya.

Indikator keberhasilan budidaya ramah lingkungan sebagai strategi pengentasan kemiskinan nelayan skala kecil di lokasi pengabdian sangat tergantung pada strategi dan metode pendekatannya. Oleh karena itu strategi yang ditempuh lebih bersifat kolaboratf antara Tim Pengabdian dengan nelayan skala kecil sebagai sasaran. Selanjutanya dalam pilihan pendekatan bersifat rasional berdasarkan potensi suberdaya alam dalam hal ini jenis biota yang memiliki potensi untuk dibudidaya dan masyarakat nelayan dapat melaksanakan sesuai dengan kondisi ekonomi pada tingkat nelayan skala kecil. Pendekatan ini tentu untuk mencapai tujuan berdasarkan ciri nelayan skala kecil (small-scale fisheries) yang memiliki kebiasaan kerjasama secara kelompok dalam satu unit kerja sebagai nelayan tangkap (Basurto et al., 2013). Pendekatan yang dimaksudkan dalam kegiatan pengabdian pada masyarakat ini adalah pendekatan kooperatif. Pendekatan kooperatif memiliki keunggulan sebagai sebuah pendekatan dalam pemberdayaan masyarakat karena memiliki sifat yaitu: partisipatif, (2) koordinatif, (3) kolaboratif dan (4) konsultatif (Wright et al., 2006).

Program budidaya ramah lingkungan sesuai dengan pendekatan yang telah dirumuskan di atas dalam pelaksanaanya menggunakan metode pendididan dan pelatihan pembelajaran orang dewasa (andragogi). Adapun tahapan dalam pelaksanaan seperti pada Tabel 1 .

Tabel 1. Tahap pelaksanaan Kegiatan

\begin{tabular}{|c|c|c|c|}
\hline No & Pokok Kegiatan & Materi & Metode \\
\hline 1 & Orientasai & $\begin{array}{l}\text { 1. Pemberdayaan nelayan skala kecil } \\
\text { berbasis budidaya ramah lingkungan } \\
\text { 2. Pemetaan potensi budidaya ramah }\end{array}$ & $\begin{array}{l}\text { Diskusi informasi, } \\
\text { FGD dan Refleksi } \\
\text { Diskusi informasi, } \\
\text { FGD dan Refleksi }\end{array}$ \\
\hline 2 & $\begin{array}{l}\text { Pendampingan persiapan pelaksanaan } \\
\text { budidaya ramah lingkungan }\end{array}$ & $\begin{array}{l}\text { 1. Penyiapan lokasi dan sarana penempatan } \\
\text { budidaya ikan } \\
\text { 2. Penderan bibit ikan }\end{array}$ & $\begin{array}{l}\text { Praktek, Diskusi } \\
\text { informasi, FGD dan } \\
\text { Refleksi }\end{array}$ \\
\hline 3 & $\begin{array}{l}\text { Pendampingan pelaksanaan budidaya } \\
\text { ramah lingkungan }\end{array}$ & $\begin{array}{l}\text { 1. Pembesaran ikan pada lokasi yang sudah } \\
\text { disiapkan (keramba jaring apung) } \\
\text { 2. Pemeliharaan dan keamanan }\end{array}$ & $\begin{array}{l}\text { Praktek, Diskusi } \\
\text { informasi, FGD dan } \\
\text { Refleksi }\end{array}$ \\
\hline 4 & $\begin{array}{l}\text { Evaluasi pelaksanaan budidaya ramah } \\
\text { lingkungan }\end{array}$ & $\begin{array}{l}\text { Kelayakan secara ekonomi sebagai industri } \\
\text { yang berbasis rumah tangga }\end{array}$ & $\begin{array}{l}\text { Diskusi informasi, } \\
\text { FGD dan Refleksi }\end{array}$ \\
\hline
\end{tabular}




\section{Hasil dan Pembahasan}

Kelompok nelayan skala kecil yang menjadi sasaran dalam pelaksanaan pengabdian pada masarakat berdasarkan strategi dan pendekatan yang telah dilakukan hasilnya dirumuskan sesuai dengan tahapan pelaksanaan adalah: Pertama, Pemberdayaan nelayan skala kecil berbasis budidaya ramah lingkungan, pada tahap ini Tim pengabdian pada masyarakat memberikan orientasi tentang nilai-nilai positif budidaya ramah lingkungan dari aspek ekonomi dan konservasi lingkungan. Berdasarkan hasil analisis stelah melakukan diskusi dan refleksi dapat disimpulkan bahwa kelompok nelayan skala kecil pada dasarnya telah memiliki pengetahuan tentang budidaya, sehingga Tim lebih banyak memberikan motivasi. Nelayan skala kecil yang tergabung dalam kelompok nelayan 'bintang laut" memiliki motivasi yang cukup besar untuk melakukan budidaya ramah lingkungan sebagai suplemen matapencahrian.

Kedua, pemetaan potensi budidaya ramah lingkungan, hasil yang diperoleh pada tahapan ini adalah jenis ikan yang menjadi prioritas yang menjadi pilahan kelompok nelayan skala kecil untuk dibudidayakan. Jenis ikan yang paling dipilih adalah jensi ikan baronang. Hal ini disebabkan karena ikan baronag ketersediaan cukup banyak di wilayah perairan pesisir Desa Ketapang Raya. Jenis lain yang dapat dibudidaya menurut para nelayan adalah cumi-cumi yang banyak hidup di sekitar areal padang lamun, crabs. Selanjutnya jenis lain yang dapat dikembangkan adalah kepiting bakau.

Ketiga, penyiapan lokasi dan sarana penempatan budidaya ikan, lokasi contoh budidaya berdasarkan hasil diskusi dan refleksi dengan kelompok nelayan pembudidaya "bintang laut" bahwa lokasi yang baik adalah di sekitar kramba apung yang digunakan oleh anggota kelompok sebagai alat untuk menangkap bibit udang lobster. Oleh karena itu lokasi contoh untuk budidaya ramah lingkungan tidak menjadi faktor yang menghambat. Pada kegiatan pengabdian pada masyarakat ini menggunakan satu contoh Kramba Jaring Apung (KJA) sebagai contoh untuk pelaksanaan budidaya ramah lingkungan.

Keempat, pendederan benih (stoks) ikan, sistem pengumpulan benih ikan dikoordinasikan oelh ketua kelompok nelayan "bintang laut". Dalam hal ini masing-masing anggota kelompok nelayan sepakat secara bersama untuk mengumpulkan benih ikan untuk dibudidayakan. Hasil yang diperoleh sesuai kesepakatan untuk menjadi contoh adaah jumlah benih ikan baronag yang dikumpulkan adalah sebanyak 1000 ekor. Benih ikan baronag yang telah terkumul selanjutanya disortir berdasarkan ukuran. Ikan yang masih kecil ditempatkan pada kolam kramba apung yang berbeda dan ikan baronang dengan ukuran yang lebih besar ditempatkan pada kolam pembesaran.

Kelima, pemeliharaan, pada tahap ini aktivitas yang dilakukan oleh kelompok nelayan bintang laut adalah pemeliharaan yang meliputi pemberian pakan dan keamanan. Jenis pakan yang dibutuhkan berdasarkan hasil diskusi dan refleksi Tim dengan nelayan dapat bersumber dari rucahan ikan dan algae. Hal ini dapat menggambarkan bahwa kelompok nelayan bintang laut memiliki pengetahuan yang cukup tentang jenis makanan ikan baronag. Ikan baronag adalah merupakan ikan herbivora dan jenis makanan utamanya adalah jenis rumput seperti lumut dan algae dan lamun. Namun demikian dapat juga memilih makanan lain seperti rucahan ikan agar ikan.

Keenam, kelayakan secara ekonomi sebagai industri yang berbasis rumah tangga, Hasil evaluasi Tim Pengabdian pada masyarakat bahwa budidaya ramah lingkungan dapat dikembangkan sebagai suplemen matapencaharian nelayan skala kecil pada skala rumah tangga nelayan. Hal ini disebabkan karena: (a) pelaksanaan budidaya tidak menggangu waktu nelayan untuk mencari ikan, (b) hasil tangkapan mereka yang kurang nilai ekonominya dapat disishkan menjadi pakan. Benih ikan dapat diperoleh, (c) benih ikan dapat diperoleh dari lingkungan sekitar, (d) nilai ekonomi ikan baronag cukup tinggi dan (e) nelayan yang tergabung dalam kelompok nelayan pembudidaya bintang laut memiliki sarana kramba apung untuk mencari bibit udang lobster.

Budidaya ramah lingkungan nelayan skala kecil di Desa Ketapang Raya, memiliki potensi untuk dikembangkan. Berdasarkan hasil analisis selama proses pelaksanaan pengabdian pada masyarakat dapat diidentifikasi beberapa kondisi oabjektif sebagai faktor penentu dalam pelaksanaan budidaya ramah lingkungan nelayan skala kecil adalah: Pertama, potensi lingkungan untuk 
budidaya, Desa Ketapang Raya adalah salah satu desa pantai yang memiliki potensi lingkungan cukup potensial dalam pengembangan budidaya ramah lingkungan. Beberapa potensi yang telah teridentifikasi yaitu: (a) bekas sawah garam, saat ini banyak sawah garam yang telah berubah menjadi lahan mangrove dengan luas \pm 15 ha dan lahan mangrove alami dengan luas \pm 20 ha adalah lahan yang potensial untuk melakukan budidaya kepiting bakau, (b) muara sungai (estuaria), potensi muara ini cukup besar dengan panjang lebih dari $400 \mathrm{~m}$ dari bibir pantai di antara ekosistem mangrove adalah lahan yang yang adapat dikembangkan untuk banyak jenis biota laut yang bernilai ekonomi dan (c) intertidal atau daerah pasang surut adalah merupakan areal budidaya yang sanagat baik untuk ikan dan biota laut lainnya yang bernilai ekonomi.

Kedua, potensi bibit secara alami, hasil diskusi dengan nelayan dapat memberikan informasi yang akurat berkaitan dengan jenis budidaya yang dapat dikembangkan berdasarkan potensi bibit secara alami. Namun demikian kelimpahan bibit secara alami belum dimanfaatkan untuk meningkatkan pendapatan keluarga dari nelayan. Beberapa jenis bibit adalah: kepiting bakau, ikan seperti ikan baronag, crabs, dan udang lobster.

Ketiga, hasil tangkapan ikan yang sudah berada pada kondisi yang cukup memperihatinkan bagi nelayan skala kecil. Dalam diskusi dengan nelayan saat ini pada tiap kali pergi melaut hasil tangkapan ikan lebih sering tidak sesuai dengan biaya yang dikeluarkan. Kondisi ini menyebabkan banyak nelayan skala kecil yang mencari alternatif lain dalam memenuhi kebutuhan hidup sehari-hari. Oleh karena itu budidaya ramah lingkungan dapat menjadi alternatif matapencaharian nelayan skala kecil untuk meningkatkan pendapatan keluarga. Budidaya sebagai alternatif matapencahrian memiliki makna yang cukup strategis dari sisi keberlanjutan matapencaharian dan dari sisi kelestarian lingkungan. Namaun demikian dibutuhakan uaaha keras dari nelayan skala kecil agar mereka terus termotivasi untuk melakukan budidaya ramah lingkungan.

Keempat, asepk sosial, dari aspek ini menunjukkan bahwa nelayan skala kecil sudah membentuk kelompok untuk melakukan budidaya ramah lingkungan yaitu kelompok nelayan bintang laut. Hal ini menunjukkan bahwa dari aspek sosial nelayan skala kecil memiliki kepedulian yang sereus untuk mengembangkan potensi lingkungan melalui budidaya ramah lingkungan sebagai alternatif matapencahrian.

Kelima, ada sarana kramba apung yang digunakan oleh nelayan untuk mencari bibit udang lobster. Fasilitas ini tentu dapat menjadi faktor pendorong bagi nelayan karena hanya membutuhkan sarana tempat budidaya sudah dapat melakukan budidaya. Kemudian yang keenam, nelayan memiliki pengethuan dan ketrampilan untuk mencari bibit alami, dalam hal ini nelayan sudah tidak diragukan pengetahuan dan keterampilnnya dalam mengembangkan budidaya ramah lingkungan dari aspek pengadaan bibit budidaya dari ikan dan biota laut lainnya yang memiliki nilai ekonomi tinggi.

Ketujuh, akses, salah satu faktor penting sebagai pertimbangan dalam mengembangkan budidaya laut adalah akses kelokasi. Dalam hal ini dapat diakses dengan mudah, karena semua lokasi berdekatan dengan perumahan nelayan yang akan melakukan budidaya ramah lingkungan. Kedelapan, potensi pasar, produk budidaya yang berupa ikan dan biota laut, saat ini tidak memiliki kendala dalam pemasaran. Hal ini disebabkan karena semua komudidatas hasil budidaya seperti ikan, kepiting dan udang dibutuhkan oleh masyarakat dan bahkan untuk budidaya udang lobster sudah menjadi komuditas ekspor dengan harga rata-rata Rp. 350.000,-/kg.

Kesembilan, dukungan pihak lain, dalam hal ini Pemerintah Dearah Kabupaten Lombok Timur melalui Dinas Perikanan dan Kelautan telah banyak memberikan dukungan untuk melakukan budidaya sebagai suplemen matapencaharian nelayan skala kecil. Hal ini dapat dilihat dari adanya bantuan budidaya untuk pembuatan Kramba Jaring Apung. Selaian itu dari Universitas Mataram, melalui pengabdian pada masyarakat ini memiliki makna yang cukup penting bagi masyarakat sebagai faktor pendorog dalam mengembangkan budidaya ramah lingkungan.

Budidaya ramah lingkungan cukup strategis sebagai matapencahraian alternatif nelayan skala kecil di Desa Ketapang Raya. Namun demikian masih terkendala dalam pengembangannya terutama dari aspek ekonomi nelayan skala kecil. Budidaya di laut dan muara dengan menggunakan kramba jaring apung membutuhkan investasi modal minimal Rp. 10.000.000,- untuk pengadaan sarana satu unit kramba apung dengan ukuran $64 \mathrm{~m}^{2}$. 
Kondisi ini tentu sangat berat bagi nelayan skala kecil yang tidak memiliki modal yang cukup. Selain faktor ekonomi nelayan skala kecil meskipun memiliki pengetahuan tentang budidaya ikan biota lain yang memiliki nilai ekonomi tetapi belum ada yang melakukan yang dapat menjadi contoh bagi semua nelayan skala kecil di Desa Ketapng Raya. Selain kedua faktor di atas hambatan lain adalah waktu budidaya yang membutuhkan waktu antara 3 bulan sampai 10 bulan. Kondisi ini tentu masih sangat berat bagi nelayan dan keluarga nelayan skala kecil yang sudah terbiasa memperoleh hasil dalam waktu cepat dari melaut.

\section{Kesimpulan}

Budidaya ramah lingkungan memiliki makna yang cukup startegis sebagai solusi mengatasi masalah sulitnya alternatif dalam meningkatkan pendapatan nelayan skala kecil dan kerusakan lingkungan akibat over-exploitasi oleh nelayan skala kecil. Berdasarkan proses yang telah dilakukan dalam pengabdian pada masyarakat dapat dirumuskan beberapa kesimpulan yaitu: 1) Nelayan skala kecil di Desa Ketapang Raya telah membentuk kelompok untuk mengembangkan budidaya ramah lingkungan yaitu kelompok nelayan bintang laut. 2) Tim pengabdian pada masyarakat dapat memfasilitasi kelompok nelayan bintang laut untuk memulai budidaya ikan yaitu ikan baronang. 3) Nelayan skala kecil memiliki respon yang sangat positif terhadap inisiasi yang dilakukan oleh Tim pengabdian pada masyarakat dalam mengembangkan potensi lingkungan untuk budidaya ramah lingkungan.

\section{Daftar Pustaka}

Basurto, X., A. Bennett, A. Hudson Weaver, S. Rodriguez-Van Dyck, and J.-S. AcevesBueno. 2013. Cooperative and noncooperative strategies for small-scale fisheries' self-governance in the globalization era: implications for conservation. Ecology and Society 18 (4): 38.
Dinas Perikanan dan Kelautan Kabupaten Lombok Timur. 2013. Statistik Perikanan. Selong Lombok Timur.

Karnan, M.S. Baskoro, B.H. Iskandar, E. Lubis, dan Mustaruddin, 2012a, Potensi dan tingkat pemanfaatan sumberdaya ikan unggulan di perairan Selat Alas, Nusa Tenggara Barat, Buletin PSP, 20 (4): 20-25.

Karnan, M.S. Baskoro, B.H. Iskandar, E. Lubis, dan Mustaruddin, 2012b, Perikanan cumicumi di Perairan Selat Alas Nusa Tenggara Barat. Jurnal Biologi Tropis, 13(1): 8-14.

Peraturan Menteri Kelautan dan Perikanan Nomer 1 tahuan 2015 tentang Penangkapan Lobster (Panulirus spp.), Kepiting (Scylla spp.), dan Rajungan (Portunus pelagicus spp.) Lembaran Negara Tahun 2015 Nomer 7.

Perez, M.L, M.D. Pido, L.R. Garces dan N.D. Salayo. 2012. Towards Sustainable Development of Small-Scale Fisheries in the Philippines: Experiences and Lessons Learned from Eight Regional Sites. WorldFish. Penang, Malaysia.

Profil Desa Kepatang Raya. 2014. Desa Ketapang Raya Kecamatan Keruak Kabupaten Lombok Timur.

Syukur, A. 2013. Pengetahuan Ekologi Masyarakat Lokal sebagai Indikator Penilaian Potensi Lamun (Seagrass) di Tanjung Luar Lombok Timur. Jurnal Biologi Tropis, 13 ( 2): 209217

Syukur, A., Wardiatno, Y., Muchsin, I., dan Kamal, M.M 2014. Status Trofik Ikan yang Berasosiasi dengan Lamun (Seagrass) di Tanjung Luar Lombok Timur. Jurnal Biologi Tropis, 14 (2):162-170.

Wright, A., Stacey, N. dan Holland, P. 2006. The cooperative framework for ocean and coastal management in the Pacific Islands: Effectiveness, constraints and future direction. Ocean and Coastal Management: 49, $739-763$. 